\title{
XXX. Examination of Dr. Croll's hypotheses on geological climates
}

\section{Dr. A. Woeikof}

To cite this article: Dr. A. Woeikof (1886) XXX. Examination of Dr. Croll's hypotheses on geological climates, Philosophical Magazine Series 5, 21:130, 223-240, DOI:

$10.1080 / 14786448608627836$

To link to this article: http://dx.doi.org/10.1080/14786448608627836

册 Published online: 29 Apr 2009.

Submit your article to this journal $[\pi$

Џ Article views: 2

Q View related articles $₫$ 


\section{Examination of Dr. Croll's Hypotheses on Geological Climates. By Dr. A. WoeIKoF*}

TTHE hypotheses of Dr. Croll have attracted such general 1 attention during the last ten years, especially in Great Britain, but also in the United States and other countries, that a review of them by a meteorologist is, I think, desirable. This work is just now particularly opportune, because Dr. Croll has recently published a new book on these matters $\dagger$ in which he further explains and extends his views, and replies to his critics, whilst in the preface he mentions that he wishes to derote the coming years to work in a wholly different direction. Thus we have now before us a system as complete as it is likely to be made by the author.

I do not propose to review the whole work of Dr. Croll in glacial geology and cosmology, but only to consider some points which are within my line of study.

In answer to Prof. Newcomb, Dr. Croll considers the mean temperature of laud and ocean $\neq$, and arrives at the startling conclusion that "the ocean must stand at a higher mean temperature than the land." Now, once the mean and not surface temperature is mentioned, the meaning of the author is, it seems, clear ; but the result is entirely opposed to what we know. Not only have the oceans which receive cold under-currents from polar seas a much lower mean temperature than the land, but even seas which receive no such cold water, and are known as exceedingly warm, as the Mediterranean and Red Seas, have a temperature considerably lower than the land.

It might perhaps be remarked, that Dr. Croll's startling statement is a simple " lapsus penne," "and that he does not consider the mean temperature of the whole volume of ocean water, but the mean annual temperature of the surface; yet, especially from p. 33 , it is seen that this is not so. Dr. Croll considers the difficulty of the sea "getting quit of its heat as rapidly as the land;" and in this passage, as in the former, he seems entirely to have forgotten the mobility of the particles of water, which is so exceedingly important and so essentially affects the thermal relations of water by the convection-currents which it causes. (A few pages before he mentions the

* Communicated by the Author.

+ 'Climate and Cosmology,' Edinburgh, 1885.

P. 26 and following.

$\S$ I understand the mean temperature as that of the whole column of water from top to bottom. 
mobility of the particles, but only as causing the removal of heat from the tropics by ocean-currents.) Dr. Croll seems to think that the high temperature of the surface of the ocean is caused by the difficulty with which water gets rid of its heat by radiation, as if, here as in the case of land, loss of heat by radiation caused a low temperature of the surface.

Now this is evidently not the case, and the convectioncurrents originating as soon as the surface temperature sinks below that of the stratum immediately under it, bring the latter to the surface, and thus maintain constantly a higher temperature of the surface than of the other strata, although they are rather conducive to a loss of heat by the whole mass, as the colder water sinks to the bottom, where it is out of the reach of the radiant heat of the sun, and receives heat only by the slow process of conduction*.

Dr. Croll does not see that, instead of "the difficulty of the water to get rid of its heat," he really considers the cause of the high temperature of the surface of the ocean; and here misses the most efficient cause.

The next point I have to notice is this: "The quantity of heat lost by expansion must therefore be trifling in comparison of that lost by radiation; and although the heat lost by expansion is fully restored by compression, yet the air would reach the earth nearly entirely deprived of the heat with which it left the equator. All that it could possibly give back would be the heat of compression; and that would hardly be sufficient to raise the air at $-50^{\circ} \mathrm{F}$. to the freezing-point." $\dagger$

As before this, Dr. Croll considers the temperature of the upper atmosphere, even under the equator, to be $80^{\circ} \mathrm{F}$. below freezing-point; and as this is reached, according to him, at such a beight that the air, returning towards the surface of the sea, would be warmed to the freezing-point, it is clear that, in his opinion, the atmosphere is in a state of unstable equilibrium, because otherwise the temperature at which the upper strata arrive at sea-level could not be lower than the existing temperature of the louer strata; but in Dr. Croll's opinion it is $48^{\circ}$ lower, as the mean temperature of the equator is about $80^{\circ} \mathrm{F}$., and the air of the higher regions, in sinking to sea-level, would bring with it a temperature of $32^{\circ} \mathrm{F}$. Now if this was really the case, if there existed an unstable equilibrium, why do not convection-currents of great magnitude arise in our atmosphere and bring a temperature of $32^{\circ}$ to the sea-lerel at the

* I consider here the case of a bcdy of water having constantly a higher temperature than that of the maximum density. 'The oceans are certainly in that state.

+ Pp. 2.5 and 26. 
equator? The reason why such convection-currents do not arise is, that the normal state of the air is a stable equilibrium, even a very stable one, so that if, by any cause, the higher strata be forced down, they would acquire, by compression, a much higher temperature than the lower bave.

An unstable equilibrium, a few cases excepted * exists only in the lower strata np to a few thousand feet, and this only in the day-time, when the surface of the ground is much heated by the sun. It disappears abont sunset, or eren somewhat earlier. It does not occur in winter in high or cren in higher middle latitudes (say, from $50^{\circ}$ onward). All this has been established by so many observations in mountain-countries and in balloons that it can scarcoly be doubied.

In any case, if Dr. Croll doubts such well-known facts, $i . e$. if he doubts that between the lower strata of air and those some tens of thousands of feet high there exists a stable equilibrium, the onus probandi rests with him. In fact, a temperature of $-50^{\circ} \mathrm{F}$. must occur at such a considerable height above sea-lerel, that the air, if forced down, would arrive warmer, and not colder, than the air existing at sea-level.

Besides, I maintain that the radiation of particles of air is but a very trifling cause of loss of heat by our globe, and that by far the principal causes of it are the radiation of the surface of the ground (or snow) and that of the surface of the water. If the lowering of temperature of the surface of land and of the air be considered, the loss of heat by radiation of the surface of the ground (and snow) is by far the most inportant.

I can much better agree with Dr. Croll in what he remarks about the conservative chancter of snow once formerl, thougl, as will be seen further on, I do not agree as to the importance of winter in aphelion during high excentricity. Besides, I think Dr. Croll does not well understand the cause of the fogs, which have been so often noticed in high latitudes in summer. He thinks the fogs are caused directly by the melting of the snow, and, interposing a screen between the sun and snow, are effectual in lessening the amount melted.

The melting of the snow by the sun has not the power to cause fogs by itself. On extensive continental regions of Europe, Asia, and America snow lies in winter, and is melted from March to June, yet fogs are of exceedingly rare occurrence during that time, and they are more frequent at night, $i$. $e$. are rather instrumental in preventing the loss of heat by radiation than the heating influence of the sun's rays. In

* For example, in thunder-storms, hail-storms, \&c. 
the same regions fogs are frequent in autumn during anticyclones. The cause of these fogs is the same as that of the London fogs, $i$. e. the temperature of the river- or lake-water is much higher than that of the air, and thus the vapour is soon condensed. Neither are fogs common in summer over mountain-snow and glaciers, notwithstanding the great amount of melting. But fogs are experienced on the sea in the vicinity of melting ice, because here we have two masses of air, of unequal temperature, both nearly saturated, and their meeting must produce saturation, $i$. $e$. fogs. Thus it is easy to see that fogs are not necessary consequences of the melting of snow and ice per se; but some other conditions are necessary for them; and Dr. Croll has no right to say about a glaciated country at some distance from the sea, "Fogs prevent, to a great degree, the melting of the snow and ice."

Mr. A. R. Wallace* has mentioned that in Northern Siberia the powerful sun of June cannot melt the snow until the warm southerly winds bring warm air. In so far as the beginning of melting depends on this, I am quite of the same opinion; but Dr. Croll is wrong when he too much extends the influence of these southeriy winds, and believes them to prevail in summer on the north coast of Siberia. On the contrary, cold winds from the sea prevail in summer and certainly chill the air, while southerly winds prevail in winter. Thus Dr. Croll's hypothesis, "Matters would be still worse if these southerly winds, instead of ceasing, were simply to change from June and July to December and January; for then, instead of producing a melting effect, they would greatly add to the snowfall," $\dagger$ is realized as far as the winds are concerned; but the snowfall of winter is exceedingly light, because the southerly winds come from the colder interior of the continent; and, besides, they are descending winds, and in descending become relatively dry. We know these facts from the observations of Wrangell and Anjou at Nijnekolymsk and Ustjansk ; and they were confirmed by the recent observations of the Russian polar station of Sagastyr at the mouth of the Lena $¥$.

Dr. Croll returns over and over again to the importance of knowing the temperature of space, as well in "Climate and Time' as in his new book; and in the latter he is rather in favour of a lower value for it than that of Herschel and Pouillet, which he admitted in 'Climate and Time.' He thinks this knowledge of the utmost importance for the determina-

* 'Island Life,' p. 135.

+ P. 88.

$\ddagger$ Iswestia of the Russ. Geogr. Soc. 1885, no. 4. 
tion of the temperatures which obtained during high excentricity and winter in aphelion; and repeatedly be admits that the temperature of a place, other things being equal, is proportional to the heat received from the sun. To make us quite sure of his meaning, he has a table in 'Climate and Time,' p. 320 , where be gives the value of excentricity for different periods, and the midwinter temperature of Great Britain for periods of great excentricity and winter in aphelion. So, for example, it was, according to him, $-6^{\circ} \cdot 3 \mathrm{~F} .850,000$ years ago, when the excentricity was $0.0747 ; 1^{\circ} .3 \mathrm{~F} .210,000$ years ago, excentricity 0.0575 , \&c. The temperatures of Great Britain are evidently given only as an illustration ; and there is no doubt that a similar decrease of temperature was experienced, according to him, even in the midst of the Atlantic Ocean. Admitting even the present mean winter temperatures there to be $6^{\circ} \mathrm{F}$. higher than in Great Britain at the same latitude, we shonld then have, at the highest excentricity, with winter in aphelion $-0^{\circ} .3 \mathrm{~F}$. and $4^{0.7} \mathrm{~F} .210,000$ years ago $i$. $e$. temperatures which were possible only if the ocean was corered with solid ice-which is an impossibility with anything like the present geographical conditions ; and Dr. Croll repeatedly admits that they have not changed since the glacial epochs.

It is exceedingly strange that Dr. Croll has not tried how his method works when applied to the existing mean temperatures of different latitudes. The mean temperatures at intervals of $10^{\circ}$ have been caleulated by different scientists. I use the calculation of Ferrel as the most recent. The mean temperature of January may be regarded as the result of the position of the earth towards the sun at the winter solstice. Thus, if we compare the mean January temperature of $50^{\circ}$ and $60^{\circ} \mathrm{N}$., we have

$$
50^{\circ} \mathrm{N} ., 21 \cdot 3, \quad 60^{\circ} \mathrm{N}, 1 \cdot 7 .
$$

The quantity of solar heat received at the winter solstice at the 60 th parallel $\mathrm{N}$. is but 0.35 of that at the 50 th parallel $\mathrm{N}$. Thus, if the temperature of the former was less in proportion to the quantity of solar heat received, it should be $=-147^{\circ} .9 \mathrm{~F}$. It is easy to see how large the discrepancy is.

Dr. Croll ascribes the relatively small decrease of temperature with latitude to the influence of ocean-currents, which abstract warm water from the tropics and bring it to high latitudes. But on the $60^{\circ} \mathrm{N}$. there is considerably more land than on the $50^{\circ} \mathrm{N}$, and air over the land under $60^{\circ} \mathrm{N}$. is colder than over the sea.

But to be quite sure of getting beyond the influence of 
ocean-currents, I will take the mean January temperature in the strictly continental climate of Eastern Siberia under $120^{\circ} \mathrm{E}$. According to Ferrel's tables :-

$$
\begin{gathered}
\text { Under } 50^{\circ} \mathrm{N} \text {., we have } 0^{\circ} \mathrm{F} . \\
\quad 60^{\circ} \mathrm{N} \text {. } \quad-30^{\circ} \mathrm{F} .
\end{gathered}
$$

If the January temperature decreased from $50^{\circ}$ to $60^{\circ} \mathrm{N}$, according to the hypothesis of Dr. Croll, it should be under $60^{\circ} \mathrm{N} .=-155^{\circ} \cdot 3$.

But to be quite sure of taking the most favourable case for the hypothesis of Dr. Croll, I take the highest January temperature under $50^{\circ} \mathrm{N}$. in Ferrel's tables, $i$. e. that at $20^{\circ} \mathrm{W} .=44^{\circ} \mathrm{F}$, and the coldest January temperature under $60^{\circ} \mathrm{N}$., $i$. e. that at $120^{\circ}$ to $130^{\circ} \mathrm{E} .=-30^{\circ} \mathrm{F}$. Yet, in proportion to the quantity of heat received, the mean temperature of January at $60^{\circ} \mathrm{N}$. should be $=-140^{\circ} \mathrm{F}$.

The following Table gives the results of the three cases

\begin{tabular}{|c|c|c|c|c|}
\hline & \multirow[b]{2}{*}{$\begin{array}{l}\text { Mean tem- } \\
\text { perature } \\
50^{\circ} \mathrm{N} .\end{array}$} & \multicolumn{3}{|c|}{ Mean temperature $60^{\circ} \mathrm{N}$. } \\
\hline & & $\begin{array}{l}\text { On the } \\
\text { hypothesis } \\
\text { of } \\
\text { Dr. Croll. }\end{array}$ & Actual. & Difference. \\
\hline $\begin{array}{c}\text { Mean January tempera- } \\
\text { ture of all meridians. }\end{array}$ & $21 \cdot 3$ & $-147 \cdot 9$ & 17 & $14 \stackrel{9}{9} 6$ \\
\hline 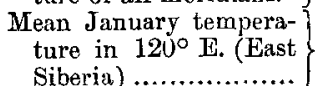 & 0 & $-155 \cdot 3$ & -30 & $125 \cdot 3$ \\
\hline $\begin{array}{r}\text { Mean January tempera- } \\
\text { ture of warmest meri- } \\
\text { dian under } 50^{\circ} \mathrm{N} \text {. and } \\
\text { coldest meridian under } \\
60^{\circ} \mathrm{N} .\end{array}$ & 44 & -140 & -30 & 110 \\
\hline
\end{tabular}
considered:-

If the discrepancies are so great in taking even the means of a whole parallel, or strictly continental climates, and even in the last example, how much must Dr. Croll's calculations for Great Britain be wrong. In so oceanic a climate an equal difference in the amount of sun-heat will certainly cause a smaller fall of temperature.

I give another example, which shows how little the method of Dr. Croll is applicable even to the mean annual temperatures. In Chapter IX. of 'Climate and Cosmology' he states that the difference of temperatures between the equator and the north pole ought to be at least $200^{\circ} \mathrm{F}$. if they were in proportion to the heat received from the sun, and the temperature of space $\left(-239^{\circ} \mathrm{F}\right.$ ) was taken as the initial one; but actually the difference is but $80^{\circ} \mathrm{F}$. This small difference, 
he thinks, is caused by the ocean-currents, which bring an immense quantity of heat from low to high latitudes. That ocean-currents have a great influence on the temperature of our earth I do not deny, but it is not so great as Dr. Croll believes.

To prove this, I will take two places in as different latitudes as possible, and both uninfluenced by the ocean-currents. Ths first is Iquitos, on the Amazons, $3 \frac{1}{2}^{\circ} \mathrm{S}$., and about 300 feet above the sea-level. The mean yearly temperature is $76^{\circ} \cdot 4$. The reduction to sea-level would make it about $77^{\circ} .8$, and the reduction to the temperature of the equator would give $78^{\circ} \cdot 3$. Now Iquitos is more than 1000 miles from the Atlantic; and though nearer to the Pacific, is separated from it by the chain of the Andes. It must be admitted, then, that this place gives us a good idea of the temperatures near the equator, uninfluenced by the heat-abstracting influences of ocean-currents.

The other place which I choose for comparison is Verkhojansk in N.E. Siberia, under $67^{\circ} \mathrm{N}$., and having the coldest winter known on our globe (January, $-56^{\circ} \mathrm{F}$.). I think it will be readily admitted that this place is out of the influence of ocean-currents, bringing heat from low latitudes, and in most favourable circumstances for radiation of heat. The mean yearly temperature of this place is $1^{0.9} \mathrm{~F}$.; the reduction to sea-level may bring it to about $2^{\circ} \cdot 3 \mathrm{~F}$.

Thus we have, out of the influence of ocean-currents, the following mean yearly temperatures at sea-level:-

$$
\begin{aligned}
& { }^{\circ} \mathrm{F} \text {. } \\
& \text { Equator . . . . . } 78 \cdot 3 \\
& 67^{\circ} \text { N. lat. . . . . } 2 \cdot 3 \\
& \text { Difference . . . . } \overline{76 \cdot 0}
\end{aligned}
$$

Reasoning on the premises of Dr. Croll, we ought to expect a difference of $172^{\circ} \mathrm{F}$. between the equator and $67^{\circ} \mathrm{N}$. The actual difference is less than half that amount (scarcely over $\frac{2}{5}$ ); yet heat is certainly not abstracted from the vicinity of the equator in the interior of South America by ocean-carrents, nor are the continental regions of N.E. Siberia wirmed by ocean-currents.

The Rev. O. Fisher $\dagger$ has already proved that if Dr. Croll's reasoning was right, the mean temperature of the equator should be higher in January than in July by $21^{\circ} \mathrm{F}$., on account of the greater nearness of the earth to the sun in the

* The actual height is not known, but in any case small.

$\uparrow$ Nature, vol. xx. p. 577 .

Phil. Mag. S. 5. Vol. 21. No. 130. March 1886. R 
former month, while it is known that at most places on the equator the warmest and coldest months do not differ even by $3^{\circ} \mathrm{F}$., and nowhere so much as by $5^{\circ} \mathrm{F}$.

Dr. Croll has answered the Rev. O. Fisher *, and this answer is a curious illustration of the difficulties in which he has involved himself. The question as to why the annual range on the equator is so small is a very simple one. The quantity of heat received from the sun varies but in the ratio of $100: 115$; and besides, the observations on which our knowledge of the temperature of the equator depends were mostly made on the sea-coast-two good reasons indeed for a small annual range. Under the $50^{\circ} \mathrm{N}$., the quantities received on the days of the winter and summer solstices are in the ratio of 100:562; and yet in some places in England the yearly range is not above $20^{\circ} \mathrm{F}$, and nowhere above $27^{\circ} \mathrm{F}$. It is thus the small annual range in many regions of the middle and high latitudes which much more needs explanation. Dr. Croll, in his reply, expresses the opinion that the northern hemisphere is the dominant one; and as the whole earth has a higher temperature in July than in January, so by the operation of this cause the normal excess of the temperature of the equator in January is weakened and even abolished. I replied to this, that the temperature on the equator was almost entirely influenced by cold winds from cold ocean-currents in some regions (the west coasts of Africa and America and the adjoining parts of the Pacific and Atlantic), and in these the equator was considerably colder in July than in January, for example at the island of St. Thomé, W. Africa, by $2^{\circ} \cdot 7$. These cold winds come from the south, while winds from the north seldom reach the equator, and can never have a depressing influence on the temperature. In most places the temperatures on the equator were influenced by the rainy season; so that when it was at its height in Jannary, this month was cooler than July. This is the case even in Batavia, $7^{\circ} \mathrm{S}$; while when January is a dry month and July rainy, the former is warmer not only on the equator, but even to some degrees north of it (so, for example, it is warmer by $7^{\circ} \cdot 2$ at Lado, Upper Nile, $5^{\circ}$ N., and by $3^{\circ} .4$ at Freetown, Sierra Leone, $8 \frac{1}{2}^{\circ}$ N.) $\dagger$.

All this is, I think, conclusive enough, and proves that Dr. Croll's system of estimating temperatures breaks down when tested seriously. Small errors would be quite natural in a

* Nature, rol. xxi. p. 129. Reprinted in 'Climate and Cosmology,' chap. iv., omitting some passages relating' to the Rev. $O$. Fisher.

+ Nature, vol. xxi. p. 249; reprinted also in the 'American Journal of Science,' 1880 . 
question of that kind; but I have shown that the errors are enormous, amounting to $100^{\circ} \mathrm{F}$. and more, i. e. they are greater than the difference of annual temperature between the equator and the north pole.

There is certainly a mistake somewhere, or, rather, the whole method is a failure. How can we judge of the change of temperature resulting from this or that distance from the smu, even if we knew accurately the temperature of space*, when we do not know the diathermancy of the atmosphere under clifferent conditions? Wo know only that it is exceedingly different according to the different quantities of carbonic acid and aqueous vapour contained in it, and in a far higher degree according to the absence or presence, in different quantities, of suspended liquid and solid particles (clouds, dust, smoke, \&c.). Thus, when we do not know how far the loss of heat is inpeded, even an accurate knowledge of the temperature of space would be of small use in this matter.

I will illustrate this by a homely example. Take a room where the fire is extinguished and the hearth or stove cold in the evening, and try to guess at the temperature the room will have in the morning. If we followed the method of Dr. Croll, we should inquire only about the outside temperature, and not about the thickness of the walls, the windows, \&c. I think that, taking the average construction of Russian, English, and Italian houses, if the inside temperature was in all three cases $65^{\circ}$ in the evening, and the outside temperature $-20^{\circ}$ in Russia, $32^{\circ}$ in England, and $45^{\circ}$ in Italy, the morning temperatures in the room would not be very different, and probably even higher in the Russian room owing to its thick walls, double windows, \&c.

It is also interesting to note that a calculation by the method of Dr. Croll of the mean January temperature under $60^{\circ} \mathrm{N}$. as given above, gives lower figures than the extreme minimum anywhere observed by reliable thermometers; this latter is about $-90^{\circ} \cdot 4 \mathrm{~F} .\left(-68^{\circ} \mathrm{C}\right.$.). Neither in the coldest part of N.E. Siberia nor in the highest latitudes of Greenland and Grinnell-land have lower temperatures been noted; and yct in Floeberg Beach the sun is absent from the horizon more than four months. The lower we make the temperature of space, the more conspicuous is the tenacity with which the surface of the earth and the lower stratum of air retain a relatively high temperature.

Dr. Croll says, in 'Climate and Time,' p. 43, "The stoppage of all currents would raise the temperature of the equator

* I just see that Prof. Langley has determined the temperature of space; but the actual figures and all details are still wanting. 
$55^{\circ}, i$. e. give it a mean temperature of $135^{\circ} . " \quad$ Now such a temperature is not only above anything known on the globe as the mean temperature even of a single month, but the absolute maximum known by exact observations does not exceed $131^{\circ} \mathrm{F} .\left(55^{\circ} \mathrm{C}\right.$.) .

Though Dr. Croll repeatedly, and quite rightly, points out the far greater influence of ocean-currents as compared with air-currents in modifying the temperature of the globe, he quite unexpectedly expresses an opinion as to the power of air-currents in cooling the temperature of the rround and air at the equator, which ought not to remain unchallenged. "No knowledge whatever as to the intensity of the sun's heat can be obtained from observations on the temperature of the air at the equator. The comparatively cold air flowing in from temperate regions has not time to be fully heated by the sun's rays before it rises in an ascending current, and returns to the temperate regions from whence it came. More than this, these trades prevent us from being able to determine with accuracy the intensity of the sun's heat from the temperature of the ground; for the surface of the ground in equatorial regions is kept at a much lower temperature by the air blowing over it than is due to the intensity of the sun's heat" *.

Certainly no physicist or meteorologist ever thought of a determination of the sun's heat by observations on the temperature of the air or the ground at the equator or elsewhere. But Dr. Croll evidently thinks that this would be poss:ble at the equator were it not for the influence of cool winds from temperate regions!

Let us first see how far facts corroborate this opinion. According to Ferrel's tables, the mean annual temperature of $10^{\circ} \mathrm{N}$. is $81^{\circ} \mathrm{F}$, of the equator $80^{\circ} .1 \mathrm{~F}$.; thus the equator cannot be cooled by winds from the northern hemisphere, as the lowest latitudes of the latter are warmer than the equator. The cool winds must come from the south. Yet the mean annual temperature of $10^{\circ} \mathrm{S}$. is $78^{\circ} \cdot 7$, i. e. only $1^{\circ} \cdot 4$ lower than the equator. Even in July, the winter of the sonthern hemisphere, the difference amounts to but $3 \cdot 8$, i.e. in the annual mean to $0^{\circ} \cdot 14 \mathrm{~F}$. for a degree of latitude, in July to $0^{\circ} \cdot 38$ for the same.

The greater part of the equatorial region consists of ocean and islands, where, at least south of the equator, the tradewinds prevail. They are not strong winds, a few ocean regions excepted, they have a very easterly direction, and blowing

* 'Climate and Cosmology,' chap. iv., and 'Nature,' vol, xxi. p. 129. 
over very large extents of sea, they bring to the equatorial regions the temperature which prevails over tropical seas. There can be no question of an influence of aerial currents from the middle latitudes on the temperature of the equator, and the latitudes $10^{\circ} \mathrm{N}$. to $5^{\circ} \mathrm{S}$. at least. Two examples show how the thermal influence of stronger winds than the trades nearly disappears as soon as they have blown over an extent of about 1000 miles of sea. The coldest region of the tropics in winter is Southern China; near Canton frosts are not rare in winter; the N.E. monsoon blows as a strong steady wind towards the coast of Cochin China; and yet at Saigon, but $12 \frac{1}{2}^{\circ}$ south of the tropic, the mean temperature of January is not below the normal of the parallel. We have :-

\begin{tabular}{|c|c|}
\hline & $\begin{array}{l}\text { Mean temperature } \\
\text { of January. }\end{array}$ \\
\hline 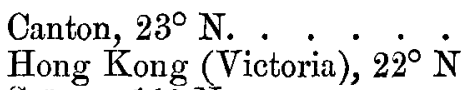 & $\begin{array}{l}. \quad 54 \cdot 8 \\
. \quad 53 \cdot 5\end{array}$ \\
\hline 110 i & $77 \cdot 5$ \\
\hline
\end{tabular}

Thus, between Hong Kong and Saigon the difference per degree of latitude is $1^{\circ} .8 \mathrm{~F}$, while the mean difference in January between $10^{\circ}$ and $20^{\circ} \mathrm{N}$. is $0 \cdot 77 \mathrm{~F}$. per degree of latitude. Thus we see, that when a cold wind from the middle latitudes reaches the borders of the tropical zone, it is soon warmed on passing over the broad expanse of the seas, and already north of $10^{\circ} \mathrm{N}$. the cooling influence is not felt. The exceedingly small difference of temperature in the zore between $10^{\circ} \mathrm{N}$. and $10^{\circ} \mathrm{S}$. is a proof that the cooling influence of winds from middle latitudes is not felt there.

Another cold wind reaches the tropical zone-the famous Northers of the Gulf of Mexico. This is not a steady wind like the N.E. monsoon of China, but a cold wind blowing at times with the utmost violence. At the mouth of the Rio Grande $\left(26^{\circ} \mathrm{N}\right.$.) frosts happen every winter, and even temperatures of $23^{\circ}$ have been observed during Northers; the latter are frequent and dangerous at Vera Cruz $\left(19^{\circ} \mathrm{N}\right.$.); but the temperature does not sink below $51^{\circ}$, and not below $59^{\circ}$ on the exposed, relatively very cold plateau of Tarifi, on the isthmus of Tehuantepec. Owing to their extreme violence, the Northers keep for a longer distance a much lower temperature than other winds of the tropical zone. Notwithstanding the Northers, the mean January temperature of Vera Cruz $\left(71^{\circ} \cdot 7\right)$ is not below the mean for tie latitade.

On the extensive wooded plains of the Upper Amazons weak winds and calms prevail for a great part of the year, and the S.E. winds of the drier months have so little the rows: 
of cooling the air, that at Iquitos the absolute minimum during a year was $66^{\circ} \cdot 8 \mathrm{~F}$. It is clear that in continental regions also, cold winds from the middle latitudes do not reach the equatorial zone.

It may be fairly asked, Where and how did Dr. Croll get his opinion about the cooling influence of winds from middle latitudes on the temperature of the equatorial regions? Would it not have been better to inquire about some of the best-known facts of climatology, before speculating " à perte de vae," and bluntly stating that the mean temperature of the equator would be $55^{\circ}$ above what it is now, if it was not for the heat-abstracting action of ocean-currents? Why, on the Upper Amazons there is no such heat-abstraction ; aerial currents can certainly not have a cooling influence of even a degree F.; and yet the mean temperature, reduced to sea-level, is not anything like $135^{\circ} \mathrm{F}$., but below $80^{\circ}$. Besides the immense influence of the diathermancy of the atmosphere and its enormous variations in time and place, another exceedingly important consideration has been overlooked by Dr. Croll, viz. the very great difference of continent and ocean in the matter of temperatures, the fact that an equal loss of heat, expressed in calories, will have a very different infuence on temperatures, both on account of the great caloric capacity of water and of the mobility of its particles. I must add that the latter condition is too often lost sight of, not only by Dr. Croll, but by many other scientists, in their speculations on the influence of a solid or liquid substratum on the distribution of terrestrial temperatures.

Besides, we have the formation of ice on the waters, which also has a great influence on the temperatures.

Thus it is easy to see, that the question how great will be the temperature of the air at a given place, say in midwinter, when the distance of the sun is greater or less than at present, cannot be answered, even approximatively, especially in the exceedingly crude way in which it is put by Dr. Croll, i. e., without distinguishing high and low latitndes, continent and ocean, \&c. One thing is certain, that such a change will certainly have a greater influence on the temperatures in the interior of continents than on the oceans and their borders. The caloric capacity of water is so great, and the mobility of its particles so effectual in resisting a dimination of the surface-temperature (by the convection-currents it causes), that I doubt very much if, during a great excentricity and winter in aphelion, the surface-temperature of the oceans can be lower in winter than now. The difference in the quantity of sun-heat is too small and too fleeting to give an appre- 
ciable difference in winter, and, as in the year there is no difference in the quantity of heat received by the waters, I think there will be no difference in the temperature of the waters, and thus no influence of great excentricity and winter in aphelion on the ocean temperatures, and also no greater snowfall than now. As to the continents, I admit that, though we are unable to calculate the rate of decrease of temperature of the winter months under these conditions, there is no doubt that it will be appreciable, and be the greater the less a given place is under the influence of the seas.

But what has this to do with glaciation? Even now, the temperatures in the interior of large continents are low enough in midwinter to allow of the snow remaining on the ground for some weeks, not only under $45^{\circ} \mathrm{N}$., but under $40^{\circ} \mathrm{N}$. And yet we have no glaciers on the North-American continent, which reaches to $71^{\circ} \mathrm{N}$., or on the Asiatic, which reaches to $78^{\circ} \mathrm{N}$., except in high mountain-regions, because the snowfall of winter is so small that it is melted in summer. Even the mountains of N.E. Siberia have no glaciers.

The greater part of the snow which lies on the ground in N.E. Siberia falls in autumn, when the air contains vapour of water enough to allow of a great precipitation ; the snowfall of winter contributes very little. Now what would a further lowering of the temperature of winter produce? A further diminution of the quantity of the falling snow. It would then even sooner be melted in the warmer summer months.

The cold of winter in the interior of large continents of high latitudes, especially that of Asia, has very important indirect results: the high pressure and the resulting cold and dry winds of winter, especially towards the $\mathrm{S}$. and $\mathrm{E}$. of the region of high pressure. These winds, the cold dry winter monsoon winds of Eastern Asia, are unfavourable to snowfall, so that in the interior of Transbaikalia, for example, with mean winter temperatures of $-13^{\circ} \mathrm{F}$. and below, there is generally too little snow for sleighing; and if the quantity of snow falling near the mouth of the Amoor is larger, it falls almost entirely in Octoher and November, $i$. e. at the beginning of the cold season, and in the few days with east winds, which bring warmer and moister air from the seas, not yet frozen in these months.

A lower winter temperature and an earlier beginning of the cold in the interior of Asia would increase the pressure towards the north and the interior of the continent, and thus give a greater impetus, strength, and duration to the dry N.W. winds, and so be even less favourable to snowfall and an accumulation of snow. 
In summer the winds in Eastern Asia are S.E., and bring clouds and rain far inland. Owing to the high iemperature of the continent and of the surrounding seas, rain and not snow falls even at great heights, for example, up to 15,000 feet in the mountains of Kansu in Western China $\left(37^{\circ} \mathrm{N}\right.$.). Thus the heavy rains of summer are not favourable to an accumulation of snow, but, on the contrary, assist in melting the small quantity which may remain on the ground.

During a high excentricity and winter in aphelion the temperature must be higher in summer, and this would cause a lower pressure on the plateaux in the interior of Asia. This would increase the difference of pressure between the ocean and the interior of the continent, and give a greater impetus to the moist winds and bring larger quantities of rain, at least where the air is ascending. Such conditions would then favour the melting of snow to a greater height than now. At present, in Northern Thibet for example, permanent snow is found at 17,000 feet; then it would disappear perhaps even to 20,000 feet.

The climatic conditions of Asia show us, so to speak, the normal reactions between continent and ocean. Everywhere there is a tendency towards a higher pressure in the interior of continents in winter and on the oceans in summer, and to winds from the first in winter, from the second in summer; that is, there are what Coffin calls monsoon influences. A colder winter in the interior of the continents, with an unchanged temperature on the oceans, would certainly strengthen the winter winds from the interior, and thus bring more cold dry weather than is experienced now, and reduce the precipitation in winter. Such conditions are certainly not favourable to a greater accumulation of snow than prevails now. The Ural Mountains have, as well as those of Norway, prevailing W. winds and a much colder winter ; but, on account of the smaller snowfall, no permanent snow and no glaciers, while the W. side of the Scandinavian mountains has enormous glaciers. If a high excentricity with winter in aphelion can have a considerable influence on climates, it would give to Western Europe colder winters with a greater proportion of dry east winds, and warmer summers, both conditions unfavourable to glaciation.

It has long seemed to me that those who have expressed an opinion on the favourable influence of winter in aphelion on glaciation, from Adhémar to Dr. Croll and his followers, have been influenced by the present difference of the northern and southern hemispheres. The glaciation is far more prevalent in the latter, and this has been ascrined to winter in aphelion on the 
well-known principle " post hoc, ergo propter hoc," as it gave a ready explanation of the former glacial periods of tile northern hemisphere. I am quite sure that Dr. Croll was also influenced by the present differences of the two hemispheres.

Dr. Croll has long been an advocate of the wind theory of ocean-currents and has proved that, at present, a considerable quantity of warm water is brought by these currents from the southern to the northern hemisphere and serves to warm the latter. In these two questions be has rendered good service to science. The transport of warm water from the sonthern to the northern hemisphere is a fact; but what is the canse ? Dr. Croll believes the cause to be, at least indirectly, winter in aphelion, which brings, especially during high excentricity, but to a certain degree even now, a host of other indirect results, by which the given hemirphere is cooled, its tradewinds are strengthened, and bring the more warm water into the other hemisphere, the higher the excentricity. I hare shown above that the cause assigned by Dr. Croll is inadequate to produce any considerable lowering of temperature on the ocean in winter, and that cven the small difference perhajs possible must be regained in summer. Thus winter in aphelion cannot cause the change in the velocity of the tradewinds and their more southerly extension when winter in aphelion exists in the northern bemisphere, and the reverse during winter in aphelion in the southern hemisphere. Why, then, are the trades of the southern hemisphere blowing into the northern at present, and also the conditions more favourable to glaciation in the southern than in the northern hemisphere? There are certainly good reasons for that.

1. The extent and depth of the oceans of the southern hemisphere. This gives a greater steadiness and force to the winds of that hemisphere; and the difference is even more marked in the westerly winds of middle laitudes than in the trades, but is certainly well seen in the latter. Now land acts in two ways on the trade-winds: it realkens them first by the increase of friction. But this is not all: the trades, fow oceanregions excepted, are not strong winds; they are important on account of their extent and steadiness. The coradient which causes them is small. Now in such eases land, even if' it is not a continent but only a cluster of small island, has a great influence on trade-winds in causing local gradients, which may have even an opposite direction to the general gradients, thus causing different and sometimes opposing winds. The land-and sea-breezes and the monsoons are cases in point. Even where the disturbances of the normal ocean gradients is not large cnough to cause monsoons, we see generally the 
trades oftener interrupted in summer, when they are weaker, and when local thunderstorms and rains are more frequent on land. For the two reasons given, the trades of the southern hemisphere must be more extensive and stronger than those of the northern.

2. The relatively small extent of sea in middle latitudes of the northern hemisphere in comparison with the southern, must tend to warm the seas of the former, even if the quantity of warm water from the tropical seas reaching them be equal. Thus, generally in middle latitudes, the evaporation goes on at a higher temperature from the seas of the northern than of the southern hemisphere. Now, this has a very great influence on the resulting precipitation; when the evaporation goes on at or near $32^{\circ}$, there is much more probability that the resulting precipitation will be snow and not rain even on lowlands; the higher the temperature at which the evaporation takes place, the greater must be the height at which snow can fall, on account of cooling by expansion.

3. Not all cold seas are favourable to glaciation. If they are surrounded by land on which the winters have a temperature much below $32^{\circ}$, they will be covered with ice, and thus evaporation will be checked just at the time when it is the most favourable to snowfall; the ice of the sea will be covered with snow; the temperature of the air over it may be very low, but the snowfall will not be great; and thus the conditions not favourable to glaciation. Such is the condition of many seas of the northern hemisphere, as the Arctic Ocean north of Siberia, the Kara Sea, the bays and inlets north of the NorthAmerican continent, the sea of Okhotsk, \&c., which are covered with ice for many months. These conditions are favourable to a long and cold winter, but not to a large snowfall and the resulting glaciation. The observations made at many points of the coasts of Siberia and the North-American archipelago have shown that the snowfall is exceedingly light. The seas of the higher southern latitudes are deep and not surrounded by land, and thus by far not so ice-bound, both on account of the absence of very low temperatures favourable to the formation of ice, and of the rupture of the ice, when formed, by winds and currents. Such seas as these are favourable to snowfall and glaciation on land, as even in midwinter there is a great extent of water which evaporates freely. The only parts of the northern hemisphere where glaciation is considerable outside of high mountains, is the region from Greenland to Francis-Joseph Land; but here we have rather cold seas, which are yet not entirely ice-bound even in winter. These seas are more favourable 
to snowfall and glaciation than those around Great Britain, because they are colder, and than those of the North-American archipelago, the Kara Sca, and the Arctic Ocean ahout Siberia, because they are less ice-bound in the cold season.

4. The intense glaciation of the highest southern latitudess gives an enormous quantity of icebergs floating northwards, $i$. $e$. to the seas of lower latitudes: As the surface of the southern seas to about $62^{\circ} \mathrm{S}$. is below $32^{\circ} \mathrm{F}$., oren in millsummer, the icebergs cannot melt till they reach that latitude, and their immense size enables them to reach sometimes even the 35th parallel S. They certainly cool the waters, and thus produce conditions favourable to glaciation eren in lower middle latitudes. This, besides, is a further direct cause of lower temperatures, and an indirect cause of stronger and more extensive trade-winds, which reach to beyond the equator and bring much warm water to the northern hemisphere. The geographical position is also farourable to this, especially the situation of Cape S. Roque and its vicinity.

It is easy to see from all this, that there is no necessity to seek far for the reason of the difference of the northern and southern hemispheres as to glaciation, without calling in aid the winter in perihelion of the former and the winter in aphelion of the latter; much simpler canses explain the result. The operation of these causes is exceelingly well illustrated in the glaciation of a part of the higher latitudes of the northern latitudes, while to the east and west there is none, with lower mean annual temperatures.

I take another example from the southern hemisphere. Its general geographical conditions are favourable to glaciation, but by no means everywhere equally. Thus the higher latitudes of the eastern part of South America have as little suow, even in winter, as the warmest parts of the European continent under the same latitudes; while a degree or two to the south, South Georgia is deeply glaciated. As to Sonth America, I must disagree also with Mr. A. R. Wallace * as to the condition of this continent being a proof of the infuence of winter in aphelion on glaciation. Besides what is stated above as to the conditions of the eastern part of the continent, I may mention the absence of snow and glaciers from the highlands of the Atacama Descrt (above 10,000 feet high), and those between the coast and Lake Titicaca (about 14,000 feet). Only in the west of the continent, and sonth of $35^{\circ} \mathrm{S}$, does glaciation prevail. But where, in the northern hemisphere, have we so enormous an extent of sea westwards, with

$$
\text { * 'Island Life,' p. } 142 \text { and foll. }
$$


such regular brisk west winds, bringing an immense quantity of vapour, which is condensed as snow? The amount of precipitation on the west coast and the western slope of the mountains of South America, south of $40^{\circ} \mathrm{S}$., is scarcely equalled anywhere in the tropies, and, besides, the greatest part falls in the cold season. The same may be said of the west coast of the southern island of New Zealand, where also high mountains rise, and to the west is an immense stretch of ocean, uninterrupted to the E. coast of South America. The snowfall is enormous, and glaciers reach down to $700 \mathrm{ft}$. above sea-level; and yot the mean temperature at sea-level is higher than in other meridians of the southern hemisphere, and the greater part of the northern also.

In the two examples given above, evaporation takes place from seas of relatively high surface temperature, about $50^{\circ} \mathrm{F}$. or more, and in such cases permanent snow can exist but at a height of some thousand feet, because air rising to such a height is cooled by expansion, and its vapour precipitated in the form of snow. Mr. A. R. Wallace* has very well shown the importance of high land for glaciation; though, to my mind, he has gone too far in not admitting the possibility of glaciation on low lands.

I must conclude. An English geologist of note $†$ has called Dr. Croll's hypotheses brilliant and fascinating. So they certainly are. The originality of the conception, the fertility of resource of the author, his indomitable will, are sympathetic in the highest degree. With a melancholy feeling I must state that, interesting and important as are some parts of the system of Dr. Croll, the main points of it are opposed to the most certain teachings of meteorology, and cannot be accepted. Besides the purely geological and cosmological part of his work, which I do not consider here, and the tables of excentricity, what can be accepted? The wind theory of the upper oceanic currents, the notion of the great climatological effects of these currents (though by no means in the exaggerated extent given to them by Dr. Croll), and some of his considerations on the conservative effects of snow and ice. The main points on which rests, so to speak, the whole fabric in its explanation of glaciation and geological climates generally - the influence of winter in aphelion and perithelion during high excentricity and the calculation of temperatures in proportion to the sun-heat received-are, unfortunately, not acceptable.

Geologists will have wo look for other causes to explain the more or less frequent glacial and interglacial periods, which their studies lead them to admit.

$$
\text { * 'Island Life.' } \quad+\mathrm{Mr} \text {. Searles V. Wood, jun. }
$$

